\title{
Hegemoni Maskulinitas dalam Under The Greenwood Tree Karya Thomas Hardy
}

\author{
Agista Nidya Wardani \\ Universitas Muhammadiyah Malang \\ agista@umm.ac.id
}

\begin{abstract}
Abstrak
Penelitian ini berfokus pada bagaimana hegemoni maskulinitas yang terjadi pada tiga tokoh laki-laki di novel Under The Greenwood Tree (1872) karya Thomas Hardy, khususnya pada tokoh utama laki-laki bernama Dick Dewy. Metode penelitian yang digunakan dalam penelitian ini adalah metode deskriptif dengan menggunakan teori hegemoni maskulinitas Raewyn Connell. Dari penelitian, ditemukan bahwa Dewy tersubordinasi dari kedua tokoh laki-laki lainnya, Shiner dan Vicar Maybold, karena Dewy berasal dari kelas bawah. Namun, pada akhirnya, Dewy tidak lagi tersubordinasi karena dia memiliki sesuatu yang menjadi standar ide komunal atau ide masyarakat untuk dianggap sebagai laki-laki yang kuat, yaitu memiliki kekayaan dalam jumlah banyak.
\end{abstract}

Kata kunci: hegemoni; maskulinitas; subordinasi

\begin{abstract}
This research focuses on hegemony of masculinity in three male characters in Under The Greenwood Tree (1872) novel by Thomas Hardy, particularly the main character named Dick Dewy. The method used is descriptive method and the theory used is Raewyn Connell's hegemony of masculinity. It is found that Dewy is subordinated compared to the other two male characters, Shiner and Vicar Maybold because Dewy comes from lower class. However, Dewy is not subordinated as he shows the communal standard to be considered as a strong man that is having lots of properties.
\end{abstract}

Keywords: hegemony; masculinity; subordination

\section{PENDAHULUAN}

Pada diskusi ini, topik yang penulis angkat adalah hegemoni maskulinitas yang terdapat pada novel Under The Greenwood Tree (1872) karya Thomas Hardy. Alasan yang melatarbelakangi pemilihan topik ini adalah penulis tertarik untuk mengetahui hubungan antara tiga tokoh laki-laki dalam novel ini karena mereka memiliki kesamaan, yaitu sama-sama memiliki ketertarikan pada tokoh perempuan utama dalam novel, yaitu Fancy Day. Kesamaan mereka tersebut membuat mereka berada di posisi yang sama sehingga memungkinkan bagi pemulis untuk meneliti lebih dalam tentang mereka. Namun, di antara kesamaan tersebut, ada hal yang 
masih perlu dipertanyakan dalam kaitannya dengan kelas, terutama pada tokoh utama pria, yaitu Dick Dewy. Untuk memulai diskusi tentang hegemoni maskulinitas dalam novel Under The Greenwood Tree, penulis akan menjelaskan tentang latar belakang sejarah pada saat novel tersebut diterbitkan dan pendekatan teoretis maskulinitas Raewyn Connell.

Era Victoria berlangsung dari tahun 1837 hingga tahun 1901, sedangkan revolusi industri berlangsung dari tahun 1760 hingga 1820. Oleh karena itu, era Victoria dipengaruhi oleh perubahan-perubahan yang terjadi akibat revolusi tersebut. Revolusi industri menimbulkan gejolak pada aspekaspek sosial, politik, hukum, dan ekonomi. Pada aspek sosial dan ekonomi, revolusi industri membuat kebanyakan penduduk 'bermigrasi' dari pekerjaan-pekerjaan yang menbggunakan peralatan tradisional ke pekerjaan-pekerjaan yang lebih modern. Perubahan ini mengakibatkan penduduk tersebut mendapatkan gaji yang besar, di saat yang lainnya tidak mendapatkan gaji yang besar. Oleh karenanya, perbedaan sosial menjadi lebih besar dan lebih luas.

Karena perbedaan sosial menjadi lebih luas, kesadaran kelas di antara masyarakat Inggris pada saat itu juga meningkat. Masyarakat kelas atas dan menengah menjadi sangat bangga akan mereka sendiri dan memandang rendah masyarakat bawah. Mereka menganggap masyarakat kelas bawah sebagai pengganggu yang menggoyang kestabilitasan masyarakat. Hal ini dikarenakan masalah-masalah sosial dan kesehata kebanyakan terjadi di dan dari masyarakat miskin (Spielvogel, 2011). Urutan hierarkis dalam masyarakat ini terjadi secara keseluruhan. Maksudnya adalah hierarki ini terjadi pada laki-laki dan wanita. Masingmasing gender di masing-masing kelas dipengaruhi baik secara langsung maupun tidak langsung oleh hierarki tersebut dalam berbagai cara. Beberapa contohnya adalah, laki-laki di kelas menengah memiliki peran sebagai kepala keluarga dan beberapa di antaranya memiliki bisnis, yang pada kasus tertentu, dibantu oleh istri mereka. Hal tersebut menandakan bahwa laki-laki dan perempuan di kelas menengah ini memiliki peran mereka masing-masing yang beberapa di antara peran tersebut berhubungan dengan keadaan finansial mereka sehingga mereka dapat menjaga zona nyaman mereka dan posisi mereka di tengah-tengah masyarakat. Sedangkan di kelas bawah, laki-laki dan perempuan sama-sama bekerja di luar rumah. Pada dasarnya, hal yang perlu diengerti adalah laki-laki dan permpuan sama-sama berusaha mendapatkan uang dengan tujuan mempertahankan hidup, meskipun permpuan mendapatkan gaji yang lebih sedikit dibanding laki-laki. Cara mereka dalam mendapatkan uang terlihat jelas lebih sulit dan menghasilkan uang lebih sedikit dibanding masyarakat kelas menengah. Perbedaan yang jelas antara kelas sosial ini mempertegas akan adanya urutan hierarkis kelas sosial.

Connell memperkenalkan maskulinitas sebagai permasalahan tentang posisi laki-laki di dalam masyarakat. Dasar pemikirannya adalah, dia percaya bahwa tentangan yang datang dari perempuan akan sistem patriarkal mestinya menimbulkan perubahan-perubahan dalam kehidupan laki-laki. Kemudian, pada 
akhirnya, Connell dikenal dengan konsep 'hegemoni maskulinitas'.

Pada akhir abad ke sembilan belas, perdebatan tentang peran laki-laki dan perempuan meningkat. Baik peran laki-laki maupun peran perempuan, dua-duanya diyakini sebagai bentukan dari masyarakat. Perbedaan antara keduanya dapat dengan mudah dikenali karena terdapat pola tertentu pada masing-masing peran tersebut. Pola-pola tersebut kemudian kita kenal dengan 'maskulinitas' dan 'femininitas' (Connell, 2005). Peran sex kemudian menjadi kabur dengan terminologi-terminologi dan segala sesuatu yang berhubungan dengan gender sebagai konstruksi budaya dan sex sebagai pemberian biologis. Peran sex sering dianggap sebagai elaborasi budaya dari pemberian biologis tersebut, akan tetapi sebenarnya hal tersebut tidak serta-merta demikian.

Pada tahun 1950-an, Helen Hacker dikenal dengan karyanya yang berjudul "The New Burden of Masculinity". Karya tersebut memiliki pengaruh yang besar pada tahuntahun berikutnya tentang keyakinan bahwa laki-laki memiliki 'sturdy oak'. Akan tetapi, keyakinan ini menjadi sesuatu yang klise pada tahun 1970-an. Pada tahun-tahun tersebut, feminisme mulai meningkat. Feminisme membawa pemikiran bahwa perempuan tidak seharusnya diopresi atau disubordinasi oleh laki-laki. Oleh karena itu, perempuan melakukan berbagai aksi untuk mencapai tujuan mereka, yaitu kesetaraan gender. Dampak dari pergerakan feminisme ini terjadi pada pertengahan tahun 1970-an. Pada saat itu, beberapa komunitas menggelar aksi kecil yang menyuarakan kebebasan laki-laki. Hal tersbut terjadi karena feminisme telah mempengaruhi kehidupan laki-laki. Aktivis laki-laki meyakini bahwa sebenarnya peran laki-laki yang dibentuk oleh masyarakat sangat menekan mereka dan oleh karenanya hal tersebut perlu diubah (Connell, 2005). Sejumlah tulisan dalam skala yang besar pada tahun 1970-an mengusulkan beberapa perubahan pada peran laki-laki dengan menggunakan berbagai cara, seperti lewat terapi, kelompok yang menyuarakan kesadaran peran laki-laki, diskusi politik, pembagian peran pada pernikahan, dan bantuan diri sendiri (Connell, 2005). Meskipun maskulinisme melawan feminisme, hal terbut tidak berarti bahwa semua aktivis dalam gerakan ini setuju bahwa terdapat urutan hierarkis antara laki-laki dan perempuan. Beberapa di antara mereka cenderung setuju bahwa opresi terhadap lakilaki dan perempuan adalah sama (Connell, 2005). Hal tersebut disebabkan karena ekspektasi sosial dan norma sosial menekan laki-laki dan perempuan dalam jumlah yang sama meskipun dari luar tampak berbeda. Perubahan historis pada peran gender antara laki-laki dan perempuan ini membuat beberapa perubahan juga pada kontrol sosial terhadap laki-laki (Connell, 2005). Masyarakat yang ingin menentang peran lama, bagaimanapun juga, terhalang oleh peran lama itu sendiri yang membuat mereka merasa gelisah. Salah satu contohnya adalah masyarakat percaya bahwa peran lama lakilaki sebagai pencari nafkah dalam keluarga merupaka cerminan dari maskulinitas. Padahal, hubungan antara menjadi pencari nafkah dan memiliki kualitas-kualitas maskulin tidaklah jelas. Namun, laki-laki yang aktif memperjuangkan peran sex mereka 
dianggap menunjukkan 'kelembutan' dan memutar khayalan masa lalu.

Peran sex selalu berubah. Ia dibangun dari interaksi setiap hari, termasuk peran laki-laki. Peran laki-laki yang bisa berubah ini berbedabeda pada kelas laki-laki yang berbeda, sebagai contohnya perlakuan sosial yang mereka terima. Isu ini menjadi fokus pada The Limits of Masculinity (1979) karya Andrew Tolson dan Masculinities and Crime (1993) karya James Messerschimdt. Perbedaan di antara laki-laki yang berbeda kelas ini menggiring pada sebuah konsep 'hegemoni maskulinitas'.

Hegemoni maskulinitas merupakan teori yang membicarakan tentang kelas-kelas yang ada pada di antara kaum laki-laki. Bahwa sebenarnya ada kelas laki-laki yang mendominasi dan ada kelas laki-laki yang tersubordinasi (Budyati, 2016). Terminologi maskulinitas itu sendiri, menurut Brod dan Kaufman, merupakan bukanlah lawan dari feminitas. Berbeda dengan pendapat Brod dan Kaufman, menurut Reeser, maskulinitas merupakan lawan dari feminitas (Hidayatullah, 2017).

Hegemoni maskulinitas ini tidak dapat dibagi dalam kategori yang tetap. Hegemoni maskulinitas bukan hanya soal perbedaan maskulinitas di kelas laki-laki yang berbeda, akan tetapi ia berkaitan dengan persoalanpersoalan yang lebih kompleks, seperti seksualitas, ras, dan lain sebagainya yang juga tidak dapat disederhanakan ke dalam kategorikategori dengan batasan-batasan yang jelas (Hidayatullah, 2017). Pelaku-pelaku dalam hegemoni maskulinitas tidak selalu laki-laki yang secara literal memiliki kekuatan. Mereka bisa jadi adalah seorang aktor film atau figur imajiner, seperti tokoh pada film (Hidayatullah, 2017) — secara lebih luas tokoh fiksi dalam berbagai karya sastra. Hegemoni biasanya terjadi secara kolektif atau dalam skala besar. Maksud dari pernyataan tersebut adalah hegemoni terjadi sebagai akibat dari ide budaya yang sama yang terjadi pada orangorang dengan jumlah yang besar yang ditambahi dengan adanya kekuatan institusional. Hegemoni berkaitan dengan hubungan gender, yaitu dominasi dan subordinasi di antara laki-laki (Connell, 2005).

Kelas dan ras adalah aspek yang penting pada hegemoni maskulinitas. Mereka selalu dikonstruksi ulang dan dibentuk ulang oleh masyarakat apapun kelasnya dan apapun rasnya. Laki-laki kelas menengah dan kelas bawah dua-duanya selalu dibentuk ulang. Hal tersebut juga terjadi pada laki-laki kulit putih dan laki-laki kulit hitam. Salah satu fenomena di antaranya adalah ketika teknologi informasi menyebar luas, jarak antara laki-laki kelas menengah dan kelas bawah bisa muncul karenanya. Akan tetapi, hal itu tidak berarti laki-laki kelas bawah selalu tersubordinasi oleh laki-laki kelas menengah. Dalam beberapa kasus lainnya, kondisi tersebut dapat terjadi sebaliknya. Fenomena lainnya adalah, atlet kulit hitam menyimbolkan kekuatan, sedangkan atlet kulit putih tidak. Di lain sisi, pemerkosa berkulit hitam memiliki peran yang penting pada politik seksual di antara orangorang kulit putih. Di antara laki-laki kulit putih, terdapat pula hegemoni yang didasarkan pada opresi institusional dan teror fisik. Dalam hegemoni maskulinitas, dominasi/subordinasi dan marjinalisasi/otorisasi selalu ada di antara laki-laki. Hegemoni maskulinitas dan maskulinitas marjinal kemudian menjadi dua 
terminologi yang menjelaskan kondisi yang berlawanan pada komunitas laki-laki yang berlawanan pula (Connell, 2005).

\section{METODE}

Tulisan ini merupakan penelitian kualitatif di mana penulis mendeskripsikan temuan dan menganalisis temuan dengan menggunakan teori hegemoni maskulinitas Raewyn Connell dan mengambil kesimpulan berdasarkan analisis dengan menggunakan teori hegemoni maskulinitas tersebut.

Objek penelitian ini terdiri dari objek material yang merupakan novel Under The Greenwood Tree (1872) karya Thomas Hardy dan objek formal, yaitu hegemoni maskulinitas antara tokoh utama pria, Dick Dewy, dengan dua tokoh pria lainnya.

Data penelitian ini didapatkan melalui beberapa tahap, yaitu penulis membaca novel Under The Greenwood Tree (1872) terlebih dahulu, mengumpulkan data berupa kutipan yang memuat tentang perihal hegemoni maskulinitas. Sedangkan untuk data analisis, langkah yang ditempuh penulis adalah mengonfirmasi data yang diperoleh dengan teori hegemoni maskulinitas Raewyn Connell, kemudian mengambil kesimpulan.

\section{HASIL DAN PEMBAHASAN}

Berbicara tentang hegemoni maskulinitas pada Under The Greenwood Tree, penulis merasa perlu untuk memberikan penjelasan singkat tentang tiga tokoh laki-laki di dalam novel tersebut. Tokoh-tokoh tersebut adalah Dick Dewy, Frederic Shiner, dan Vicar Maybold. Dick Dewy adalah anggota Mellstock Choir yang masih muda. Dia bekerja sebagai buruh pengangkut barang, yang darinya dapat disimpulkan bahwa dia merupakan laki-laki kelas bawah. Hal tersebut dibuktikan dalam novel pada "Part The First-Winter: Chapter II The Tranter's"

Tentang penggambaran rumah keluarganya yang mendukung kesimpulan bahwa dia merupakan laki-laki kelas bawah,

It was a long low cottage with a hipped roof of thatch, having dormer windows breaking up into the eaves, a chimney standing in the middle of the ridge and another at each end. The window-shutters were not yet closed, and the fire- and candle-light within radiated forth upon the thick bushes of box and laurestinus growing in clumps outside, and upon the bare boughs of several codlin-trees hanging about in various distorted shapes, the result of early training as espaliers combined with careless climbing into their boughs in later years. The walls of the dwelling were for the most part covered with creepers, though these were rather beaten back from the doorway-a feature which was worn and scratched by much passing in and out, giving it by day the appearance of an old keyhole. Light streamed through the cracks and joints of outbuildings a little way from the cottage, a sight which nourished a fancy that the purpose of the erection must be rather to veil bright attractions than to shelter unsightly necessaries. The noise of a beetle and wedges and the splintering of wood was periodically heard from this direction; and at some little distance further a steady regular munching and the occasional scurr of a rope betokened a stable, and horses feeding within it (Hardy, 2004).

Frederick Shiner adalah saingan utama Dick dalam merebut hati Fancy Day. Dia adalah seorang petani lokal yang kaya. Hal itu terlihat pada "Part The First-Winter: 
Chapter V The Listeners" tentang deskripsi rumahnya,

Farmer Shiner"s was a queer lump of a house, standing at the corner of a lane that ran into the principal thoroughfare. The upper windows were much wider than they were high, and this feature, together with a broad bay-window where the door might have been expected, gave it by day the aspect of a human countenance turned askance, and wearing a sly and wicked leer. To-night nothing was visible but the outline of the roof upon the sky (Hardy, 2004).

Shiner digambarkan sebagai laki-laki yang jahat, sinis, arogan, dan kasar. Karakternya tersebut digambarkan pada bagian yang sama dan bab yang sama, yaitu,

They had reached the end of the second verse, and the fiddlers were doing the up bow-stroke previously to pouring forth the opening chord of the third verse, when, without a light appearing or any signal being given, a roaring voice exclaimed"Shut up, woll "ee! Don" $t$ make your blaring row here! A feller wi" a headache enough to split his skull likes a quiet night!"... A light now flashed into existence, the window opened, and the farmer stood revealed as one in a terrific passion (Hardy, 2004).

Sementara itu, Vicar Maybold adalah pendeta baru di Mellstock. Sebagai seorang pendeta, dia adalah seseorang yang baik dan bijaksana pada hal tertentu dan dihormati oleh penduduk desa. Salah satu kebaikannya adalah ketika dia menarik lamarannya ke Fancy setelah dia mengetahu bahwa Fancy akan menikah dengan Dick. sementara itu, kebijaksanaaannya terlihat pada akhir cerita pada "Part The Third-Summer: Chapter VII Second Thoughts",

The last written communication that ever passed from the vicar to Fancy, was a note containing these words only: "Tell him everything; it is best. He will forgive you." (Hardy, 2004).

Akan tetapi, dia sedikit tidak sopan pada hal tertentu. Pada bagian yang sama dan bab yang sama, dia digambarkan seperti berikut ini,

The vicarage front was their next field of operation, and Mr. Maybold, the latelyarrived incumbent, duly received his share of the night"s harmonies. It was hoped that by reason of his profession he would have been led to open the window, and an extra carol in quick time was added to draw him forth. But Mr. Maybold made no stir. "A bad sign!" said old William, shaking his head. However, at that same instant a musical voice was heard exclaiming from inner depths of bedclothes-"Thanks, villagers!" "What did he say?" asked Bowman, who was rather dull of hearing. Bowman"s voice, being therefore loud, had been heard by the vicar within. "I said, „Thanks, villagers!" cried the vicar again. "Oh, we didn" $t$ hear "ee the first time!" cried Bowman. "Now don"t for heaven"s sake spoil the young man"s temper by answering like that!" said the tranter. "You won" $t$ do that, my friends!" the vicar shouted. "Well to be sure, what ears!" said Mr. Penny in a whisper. "Beats any horse or dog in the parish, and depend upon "t, that"s a sign he"s a proper clever chap." "We shall see that in time," said the tranter. Old William, in his gratitude for such thanks from a comparatively new inhabitant, was anxious to play all the tunes over again; but renounced his desire on being reminded by Reuben that it would be best to leave well alone (Hardy, 2004). 
Agar diskusi tentang maskulinitas di antara tiga tokoh laki-laki ini menjadi lebih mudah, penulis menambahkan informasi tentang bagaimana Fancy. Hal ini sangat penting karena dengan mengetahui karakter Fancy, kita dapat melakukan semacam 'perbandingan' antara Fancy dan tiap tokoh dari ketiga tokoh laki-laki tersebut. Fancy adalah seorang guru pada sekolah jamaah gereja dan pemain piano pada paduan suara Mellstock. Karena dia adalah guru, maka dapat disimpulkan bahwa dia berasal dari keluarga menengah. Status sosialnya digambarkan melalui deskripsi tentang rumah keluarganya pada "Part The Second-Spring: Chapter VI Yalbury Wood and The Keeper's House",

The window-sill of the front room was between four and five feet from the floor, dropping inwardly to a broad low bench, over which, as well as over the whole surface of the wall beneath, there always hung a deep shade, which was considered objectionable on every ground save one, namely, that the perpetual sprinkling of seeds and water by the caged canary above was not noticed as an eyesore by visitors. The window was set with thickly-leaded diamond glazing, formed, especially in the lower panes, of knotty glass of various shades of green. Nothing was better known to Fancy than the extravagant manner in which these circular knots or eyes distorted everything seen through them from the outside-lifting hats from heads, shoulders from bodies; scattering the spokes of cartwheels, and bending the straight fir-trunks into semicircles. The ceiling was carried by a beam traversing its midst, from the side of which projected a large nail, used solely and constantly as a peg for Geoffrey"s hat; the nail was arched by a rainbow-shaped stain, imprinted by the brim of the said hat when it was hung there dripping wet. The most striking point about the room was the furniture. This was a repetition upon inanimate objects of the old principle introduced by Noah, consisting for the most part of two articles of every sort. The duplicate system of furnishing owed its existence to the forethought of Fancy"s mother, exercised from the date of Fancy"s birthday onwards. The arrangement spoke for itself: nobody who knew the tone of the household could look at the goods without being aware that the second set was a provision for Fancy, when she should marry and have a house of her own. The most noticeable instance was a pair of green-faced eight-day clocks, ticking alternately, which were severally two and half minutes and three minutes striking the hour of twelve, one proclaiming, in Italian flourishes, Thomas Wood as the name of its maker, and the other-arched at the top, and altogether of more cynical appearance-that of Ezekiel Saunders. They were two departed clockmakers of Casterbridge, whose desperate rivalry throughout their lives was nowhere more emphatically perpetuated than here at Geoffrey"s. These chief specimens of the marriage provision were supported on the right by a couple of kitchen dressers, each fitted complete with their cups, dishes, and plates, in their turn followed by two dumbwaiters, two family Bibles, two warmingpans, and two intermixed sets of chairs. But the position last reached - the chimneycorner-was, after all, the most attractive side of the parallelogram. It was large enough to admit, in addition to Geoffrey himself, Geoffrey"s wife, her chair, and her work-table, entirely within the line of the mantel, without danger or even inconvenience from the heat of the fire; and was spacious enough overhead to allow of the insertion of wood poles for the hanging of bacon, which were cloaked with long shreds of soot, floating on the draught like the tattered banners on the walls of ancient aisles. These points were common to most chimney corners of the neighbourhood; but one feature there was which made Geoffrey"s fireside not only an object of 
interest to casual aristocratic visitors-to whom every cottage fireside was more or less a curiosity - but the admiration of friends who were accustomed to fireplaces of the ordinary hamlet model. This peculiarity was a little window in the chimney-back, almost over the fire, around which the smoke crept caressingly when it left the perpendicular course. The windowboard was curiously stamped with black circles, burnt thereon by the heated bottoms of drinking-cups, which had rested there after previously standing on the hot ashes of the hearth for the purpose of warming their contents, the result giving to the ledge the look of an envelope which has passed through innumerable post-offices (Hardy, 2004)..

Berdasarkan data tersebut yang berbicara tentang status sosial keempat karakter, maka dapat disimpulkan bahwa Fancy, Shiner, dan Vicar Maybold sama-sama memiliki status sosial yang cukup tinggi, sedangakn Dick memiliki status sosial yang lebih rendah daripada mereka.

Karena Dick memiliki status sosial yang lebih rendah daripada Shiner dan Vicar Maybold, dia tersubordinasi oleh Shiner di samping keinferioritasannya terhadap Shiner yang muncul dari dirinya sendiri, dan dia secara tidak sengaja 'kalah' dari Vicar Maybold dalam menggapai hati Facnys karena Vicar Maybold menawarkan Fancy dengan beberapa harta benda dan kenyamanan. Keinferioritasan Dick terhadap Shiner terlihat pada banyak bagian di dalam cerita. Di antaranya adalah pada "Part The Fourth-Autumn: Chapter II Honey-Taking, and Afterwards",

"Taste a bit, Mr. Dewy," she said, holding up to him a small circular piece of honeycomb that had been the last in the row of layers, remaining still on her knees and flinging back her head to look in his face; "and then I"ll taste a bit too." "And $I$, if you please," said Mr. Shiner. Nevertheless the farmer looked superior, as if he could even now hardly join the trifling from very importance of station; and after receiving the honeycomb from Fancy, he turned it over in his hand till the cells began to be crushed, and the liquid honey ran down from his fingers in a thin string (Hardy, 2004)..

dan pada "Part The Thrid-Summer: Chapter II Further Along The Road",

When an opportunity seemed to offer itself for carrying this intention into effect, they heard light flying wheels behind, and on their quartering there whizzed along past them a brand-new gig, so brightly polished that the spokes of the wheels sent forth a continual quivering light at one point in their circle, and all the panels glared like mirrors in Dick and Fancy"s eyes. The driver, and owner as it appeared, was really a handsome man; his companion was Shiner. Both turned round as they passed Dick and Fancy, and stared with bold admiration in her face till they were obliged to attend to the operation of passing the farmer. Dick glanced for an instant at Fancy while she was undergoing their scrutiny; then returned to his driving with rather a sad countenance (Hardy, 2004).

Meskipun tidak dikatakan secara eksplisit bahwa Dick inferior terhadap Shiner, sangat terlihat jelas bahwa perasaan Dick pada Shiner buka sekedar cemburu, akan tetapi dia juga merasa takut kalau Shiner akan berhasil merebut hati Fancy karena kekayaan yang dia miliki. Kekayaan yang tidak dimiliki oleh Dick membuatnya merasa inferior terhadap Shiner. Karena posisi yang berbeda dalam hal 
kelas dan status sosial ini, dalam kaitannya dengan hegemoni maskulinitas, Dick dianggap sebagai maskulinitas rendah dan Shiner adalah maskulinitas tinggi karena terdapat posisi hierarkis di antara keduanya.

Posisi hierarkis antara Dick dan Shiner tersebut diperkuat oleh sikap Geoffrey pada Dick dan Shiner. Geoffrey adalah ayah Fancy. Dia tidak setuju dengan hubungan Dick dan Fancy karena Dick berasal dari kelas bawah. Dia lebih condong untuk menikahkan putrinya dengan Shiner yang kaya. Ketidaksukaan Geoffrey pada Dick dan kesukaannya pada Shiner dapat dilihat pada beberapa bagian dalam novel. Beberapa di antaranya pada "Part The Third-Summer: Chapter III A Confession",

"Why this," she said, drying the beginning of a new flood of tears she had been going to shed, "this is the serious part. Father has told Mr. Shiner that he would like him for a son-in-law, if he could get me;-that he has his right hearty consent to come courting me!" (Hardy, 2004).

dan pada "Part The Fourth-Autumn: Chapter II Honey-Taking, and Afterwards",

"And that when she sat for her certificate as Government teacher, she had the highest of the first class?" "Yes." "Well, and do ye know what I live in such a miserly way for when I"ve got enough to do without it, and why I make her work as a schoolmistress instead of living here?" "No."

"That if any gentleman, who sees her to be his equal in polish, should want to marry her, and she want to marry him, he sha " $n$ "t be superior to her in pocket. Now do ye think after this that you be good enough for her?" "No." "Then good-night t"ee, Master Dewy." "Good-night, Mr. Day." Modest Dick"s reply had faltered upon his tongue, and he turned away wondering at his presumption in asking for a woman whom he had seen from the beginning to be so superior to him (Hardy, 2004)..

Menurut Raewyn Connell, hegemoni maskulinitas di antara laki-laki yang disebabkan oleh perbedaan kelas dan status sosial tidak terjadi karena aksi individual atau ide individual, akan tetapi ia lebih merupakan hasil dari aksi atau ide masif dan komunal. Dengan kata lain, subordinasi Dick tidak hanya dilakukan oleh Shiner akan tetapi juga oleh Geoffrey. Shiner dan Geoffrey memiliki ide yang sama bahwa kekayaan adalah segalany. Mereka yakin bahwa kekayaan dapat membuat setiap orang bahagia, termasuk Fancy.

Selain inferior dari Shiner, Dick juga inferior dari Vicar Maybold. Dia tidak merasakan secara langsung keinferioritasan ini, akan tetapi keinferioritasan ini benar-benar ada. Hal itu disebabkan oleh Dick yang tidak tahu bahwa Vicar Maybold menyukai Fancy. Keinferioritasan ini disimpulkan dari dialog antara Fancy dan Vicar Maybold pada "Part The Third-Summer: Chapter VI Into Temptation"

"Don"t refuse; don" $t$," he implored. "It would be foolish of you-I mean cruel! Of course we would not live here, Fancy. I have had for a long time the offer of an exchange of livings with a friend in Yorkshire, but I have hitherto refused on account of my mother. There we would go. Your musical powers shall be still further developed; you shall have whatever pianoforte you like; you shall have anything, Fancy, anything to make you happy-pony-carriage, flowers, birds, pleasant society; yes, you have enough in you for any society, after a few months of 
travel with me! Will you, Fancy, marry me?" Another pause ensued, varied only by the surging of the rain against the window-panes, and then Fancy spoke, in a faint and broken voice. "Yes, I will," she said (Hardy, 2004)..

Dari dialog tersebut, penulis menympulkan bahwa Fancy dengan mudah dibujuk dengan kekayaan dan kenyamanan. Masalah yang menjadi sorotan penulis di sini bukanlah pada sikap Fancy, akan tetapi bagaimana kekayaan, kelas dan status sosial menjadi begitu penting bagi laki-laki untuk membuat mereka diterima di dalam masyarakat, termasuk dalam hubungan asmara. Connell menyatakan bahwa kelas dalam hubungannya dengan hegemoni maskulinitas selalu dibentuk ulang oleh masyarakat. Pada persoalan ini, Shiner dan Vicar Maybold dibuat percaya bahwa mereka adalah laki-laki yang kuat dengan adanya kekayaan dan status sosial yang mereka miliki. Sementara itu, Dick dibuat percaya bahwa dia bukan siapa-siapa karena dia tidak kaya.

Mengingat akan hal ini, tidak mengagetkan ketika Dick memberitahu Vicar Maybold bahwa dia akan memperoleh karir yang lebih bagus. Dialog ini terdapat pada "Part The Third-Summer: Chapter VII Second Thoughts",

"You see, sir," continued the ingenuous Dick, " "twill be better in one sense. I shall by that time be the regular manager of a branch o" father"s business, which has very much increased lately, and business, which we think of starting elsewhere. It has very much increased lately, and we expect next year to keep a "extra couple of horses. We "ve already our eye on one-brown as a berry, neck like a rainbow, fifteen hands, and not a gray hair in her-offered us at twenty-five want a crown. And to kip pace with the times I have had some cards prented and I beg leave to hand you one, sir." (Hardy, 2004).

Pada dialog tersebut, Dick bahagia karena pada akhirnya dia akan menjadi lebih makmur. Kebahagiaan ini muncul setelah Dick menyadari bahwa untuk menikahi Fancy, dia harus memiliki keadaan finansial yang lebih baik. Sebagai seorang laki-laki, dia bangga akan keadaannya yang akhirnya dapat membuat status sosialnya naik. Hal tersebut sejalan dengan argumen Connel bahwa hegemoni maskulinitas selalu dibentuk ulang oleh masyarakat atau ide komunal. Oleh karena itu, beberapa laki-laki yang disubordinasi dalam hegemoni ini dimungkinkan akan melakukan sesuatu yang dapat menaikkan posisi atau status mereka di dalam masyarakat.

\section{KESIMPULAN}

Novel karya Thomas Hardy, Under The Greenwood Tree, menjelaskan banyak hal tentang maskulinitas. Novel tersebut menunjukkan bagaimana hegemoni maskulinitas yang terjadi pada masyarakat yang sebenarnya mengingat karya sastra merupakan cerminan dari fakta-fakta yang terjadi di dunia nyata. Hegemoni maskulinitas tersebut dapat meliputi permasalahan kelas, seperti yang terjadi pada Dick Dewy yang berasal dari keluarga kelas bawah. Dick merupakan contoh laki-laki yang tersubordinasi oleh kaumnya sendiri. Walaupun begitu, subordinasi ini dapat berubah-ubah karena laki-laki di dalam hegemoni tersebut pun berubah pula. Dick pada akhirnya menjadi setara dengan Shiner 
dan Vicar Maybold dan tidak tersubordinasi lagi karena dia memiliki sesuatu yang menjadi standar ide komunal atau ide masyarakat untuk dianggap sebagai laki-laki yang kuat, yaitu memiliki kekayaan dalam jumlah banyak.

\section{DAFTAR PUSTAKA}

Budyati, Laily E. (2016). Konstruksi tubuh maskulin laki-laki. Universitas Diponegoro.

Connell, Raewyn. (2005). Masculinities. Los Angeles: University of California Press.

Hardy, Thomas. (2004). Under the greenwood tree. ___ : The Project Gutenberg eBook.

Hidayatullah, Danial. (2017). Interseksi Maskulinitas dan Agama dalam Cerpen Robohnya Surau Kami karya A.A.Navis. Adabiyyāt: Jurnal Bahasa dan Sastra, l(2), 139-155.

Spielvogel, Jackson J. (2011). Western civilization: volume c: since 1789. Boston: Cengage Learning. 